\section{Queer Subject Economies. Managing Diversity and Precariousness in Neoliberalism}

(Ekonomie odmiennych podmiotów. Zarządzanie różnorodnością i niepewnościa w kontekście neoliberalnym)

\section{Volker Woltersdorff}

STRESZCZENIE: Autor artykułu przygląda się krytycznie pojęciu "zarządzanie różnorodnościa" (dotyczącym między innymi różnorodności seksualnej), którym coraz częściej posługuja się międzynarodowe przedsiębiorstwa. Analizie poddaje serię reklam odwołujących się w sposób jawny lub zawoalowany do kwestii różnorodności seksualnej w miejscu pracy lub w miejscu konsumpcji. Zwracając szczególną uwage na status odmiennych podmiotowości, autor ukazuje, jak warunki neoliberalne kształtuja odmienność. Główną tezą tego tekstu jest to, iż w dyskursie neoliberalnym odmienność nabiera znaczenia wzorowego prywatnego zarządzania niepewnymi pozycjami podmiotowymi. Stąd różnorodność seksualna jest mile widziana, o ile odmienne podmioty przejmuja indywidualną odpowiedzialność za podejmowanie ryzyka i opiekę społeczna.
This essay addresses the status of queer subjectivities in neoliberalism and analyses how queerness is shaped under neoliberal conditions. It suggests that subject formation is not detached from the economic structure that reigns the mode of production and of reproduction. It argues that queerness is signified in neoliberal discourse as a paradigm for the successful private management of precarious subject positions. Therefore sexual diversity is welcomed for the price of individual responsibility for risk taking and social care. This attitude has been referred to under the catchphrase of so called "diversity management". This new strategy asserts that valuing diversity has unlimited benefits: it fosters creativity and innovation, facilitates teamwork, and allows one to discover new markets. 


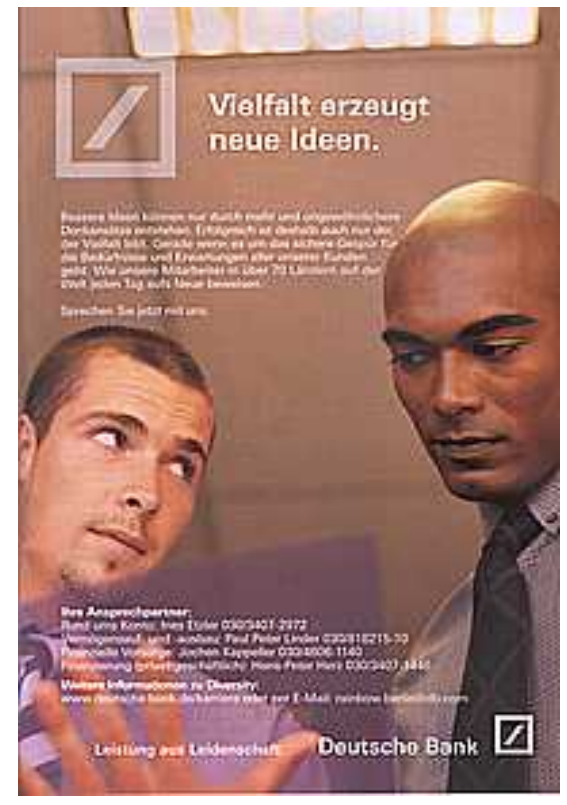

fig. 1l'd like to start with an example which seems significant to me in several ways. I'm talking about two ads by Deutsche Bank (see fig. 1) that have been repeatedly published in the Berlin monthly journal for queers Siegessaule, comparable to Replika in Warsaw, throughout the last year. The first shows two businessmen, one of light, the other of dark skin colour, glancing at each other from the corner of their eyes, presumably engaging in a flirt. The copy says: "Diversity Produces New Ideas - Better ideas can only emerge by more and unusual thinking. Therefore only the one who lives diversity can really succeed. Especially when a clear sensitivity for the needs and expectations of all our costumers is needed. Our staff members make proof of it in more than 70 countries over the world every day anew. - Talk to us now. - A Passion to Perform. Deutsche Bank."

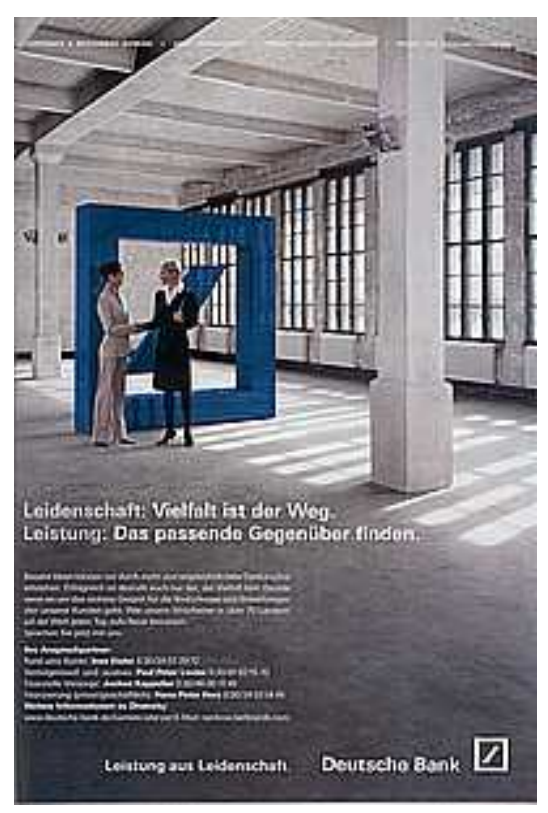

fig. 2There is also a female equivalent of this ad (see fig. 2), featuring two racially mixed businesswomen in a loft squeezing hands as if they have set the seal on an accomplished transaction. The image is less open to a queer erotic lecture. But the advertising text does not foreclose such implications as it reads: "Passion: Diversity is the Way. - Performance: Finding the Suitable Counterpart." The rest is 
identical to the all male ad.

In her ground-breaking article "Commodity Lesbianism" Ann Clark (1993) has already characterised as "window advertisement" this particular phenomenon that consists in addressing a gay and lesbian clientele between the lines without being overtly legible to an uninitiated straight audience. What seems peculiar to me, though, is the way in which racial diversity is instrumentalised to interpellate a queer subject as a precarious one. It is only by the context where the ad is placed - the queer city magazine of Berlin - that diversity becomes legible as sexual diversity. However, this meaning can always be revoked and substituted by a meaning that might be less offensive to the public opinion: the embracing of racial diversity. Racial difference becomes the visual marker of sexual deviance. Unfortunately I cannot engage further into the analysis of how neoliberalism exploits racial and sexual difference as evidence of its own modernity. I only want to state that diversity is here represented as sexualised "exotic" otherness, conflating sexual and racial difference as if interracial contacts were more open to queerness than others.

On the official web page of Deutsche Bank queer issues are only addressed under the mysterious name of "rainbow groups"[1], the word "rainbow" not even being translated into German in the
German version of the page.[2] On the one hand, queer people are welcomed as stakeholders, clients and employees of Deutsche Bank. On the other hand, their recognition remains a precarious one, for it can easily be withdrawn because it is not verbalised. Moreover, sexual diversity is integrated at a price: the production of a profitable output. In other words: deviance from the norm is granted if it pays off. Accordingly the Deutsche Bank brochure on corporate diversity management says: "Our leaders demonstrate fairness and are committed to shaping an inspirational and supportive environment that encourages employees to develop their skills and talents and to perform at their best."[3] As a consequence this translates into a pressure to perform that weighs upon queer people. Given the heteronormative logics, straight people need not make proof of the fact that their very straightness adds a surplus value to the team work's output.

Social difference, in these concepts, is addressed as cultural diversity. The social conditions that bring about these differences are not addressed. They are rather embraced and therefore reproduced because they produce an expertise that can be exploited. I'd like to call these special assets "queer skills". In order to answer the question how queer subjectivities work, queer theorists Renate Lorenz and Brigitta Kuster (2007) have coined the term "sexual labour". They call "sexual labour" the expense that needs to 
be invested in order to construct oneself as a subject with a coherent sexual and gender identity. To this regard queer and transgendered people have to perform a higher degree of self-care than others. Hence Jose Esteban Munoz (2007) speaks about "queerness's labour" in order to denominate this additional outlay.

Let me illustrate this peculiar surplus of "queerness's labour" in my examples: The Deutsche Bank ad incites us to produce various fantasies about the queering or the sexualisation of financial services. Additionally it lets us engage in fantasies, maybe awkward ones, concerning the interracial status of the imaginary couples. But it also tells us that we are responsible for these fantasies as Deutsche Bank doesn't assume responsibility for our fantasies of two fag clerks or two real estate business dykes. Furthermore Deutsche Bank affirms: "Encouraging our employees to celebrate their own diversity and that of their colleagues is fundamental to our corporate values and critical to our business success."[4] What kind of celebration of diversity has Deutsche Bank got in mind? It is very likely that there are ways to celebrate one's diversity which are not tolerable to the corporate policy while others are. We are beholden to take the risk and test it out. But how does our queer passion become a passion to perform, and yet not only a passion to perform but a passion to perform for Deutsche Bank? In other words: How do sexuality and economy interrelate in such a way that we are willing to get affectively involved with wage labour?

Allow me to make the following case: The philosopher Georg Friedrich Hegel affirmed that desire is always a desire for recognition. By promising that this very recognition can be earned, neoliberal management strategies merge queerness and economy in new and unforeseen ways.

Back in 1983 Arlie Russell Hochschild argued in her book The Managed Heart that certain wage labour, that one performed by women in particular, requires an emotional investment and affective commitment that ultimately translates to a love for labour. Labour sociology has identified this phenomenon as a "subjectivation of labour". Scholars give different reasons for the rising importance of subjective involvement. First of all they point at the growing individualisation of the workforce. It results from the end of standardised careers and lifetime job security which increases the pressure to perform. Furthermore this tendency is accompanied by a growth of the services sector, in particular the creative industry with its project based freelance economy. All these developments call for the commitment of the whole personality. On the whole, these phenomena have contributed to the rise of the so called entrepreneurial self that extends the economic logics to any domain of his or her life.[5] 
What are the characteristics of this new subject of wage labour? They are summarised in the new ideal of "employability" that is displayed in management manuals. Employability depends on the knowledge, skills and attitudes individuals possess, the way they use those assets and present them to employers. Employability is grounded in the idea of self-activation. As a matter of course, it encompasses life-long learning, personal responsibility, and individual balancing of work and life within a context of flexibilisation of working hours and dislocation of work place, which also leads to a new management of family life.

Queer employability, as the Deutsche Bank ad suggests, would then consist in the ability of identifying and dis-identifying, in doing and undoing queerness in accordance with the demands of a given situation. In contrast, undoing straightness or gender conformity is not required from straight employees. Moreover, queer employability consists in producing and managing precariousness. It requires risk awareness instead of reliance on social securities. Diversity as a neoliberal tool can thus help to undo the welfare state and replace it by workfare. Such a conception of diversity conflates individualism, employability and precariousness. In the following l'd like to develop this thought in more detail.
In social and political science "precariousness" designates the coexistence of a gain both in individualisation and in insecurity that is generated by deregulation and the undoing of traditionalism. This usage of the term refers to the academic analysis of neoliberalism and to the political movements that oppose it. To me it seems adequate to describe the contradictions and ambivalences of neoliberal transformation. Applying the term to the study of sexuality is meant as an intervention into this very discourse in order to highlight the sexual dimension of capitalism and to establish sexuality as an indispensable analytical category for the study of capitalism. Such an understanding of sexuality clearly owes to Michel Foucault's (1978) concept of the sexual apparatus ( dispositif ) that produces embodied subjects and that relates them to each other. Sexuality is thus an agent and a resource of precariousness at the very same time. It combines precarious labour conditions with subjectivities. Precarious gender and subject positions transgress traditional codes and risk to fail or collapse. The sociologist Robert Castel (2003) therefore characterises precariousness as the insecure position between social integration and dis-affiliation. Precariousness requires a technology of the self that is able to cope with and profit from the demands of risk management.

With reference to Sigmund Freud Judith Butler writes that desire emerges precisely from a moment of unpredictability and 
elusiveness. Everyday life and routine are well known as erotic turn-offs. Butler points out that sexual desire features an irreducible rest that eludes control by consciousness or by language. "I'm permanently troubled by identity categories, consider them to be invariable stumbling-blocks, and understand them, even promote them, as sites of necessary trouble. In fact, if the category were to offer no trouble, it would cease to be interesting to me: it is precisely the pleasure produced by the instability of those categories which sustains the various erotic practices that make me a candidate for the category to begin with." (1991: 14) Eroticism would then aim at transgressing the given identities of everyday life. Deregulation and precarisation thus may well correspond to certain sexual wishes. Neoliberal transformation acknowledges the sexual pleasure of risk taking but it also tries to mitigate it via risk management, thus opening it up to the purpose of mobilising new employee and consumer subjects, following the slogan: Nothing ventured, nothing gained!

One could be tempted to conclude that precariousness conflates queerness and neoliberalism. However, it is worthwhile to take a closer look on the interrelatedness of queerness and neoliberalism. I therefore like to highlight another aspect of precariousness, one of precariousness as vulnerability which figures as much in queer as in labour analyses.
In her writing Judith Butler uses the term "precariousness" for designating a fundamental dependency on the other. "As sexual, we are dependant on a world of others, vulnerable to needs, violence, betrayal, compulsion, fantasy; we project desire, and we have it projected onto us." (2004: 33) Robert Castel precisely qualifies the "zone of precariousness" as marked by an insecurity and unpredictability of the future. Hence in neoliberalism security is nothing you can rely on but it is to be actively constructed by private sustaining networks (which political science addresses as the replacing of solidarity by subsidiarity). In allusion to Foucault's "bio-power" Rosemary Hennessy calls this process "bio-deregulation": "The concept of 'bio-deregulation' addresses this process and is a useful critical lever to make visible the impact of neo-liberal capitalism on the reproduction of nature and human being."[6] 


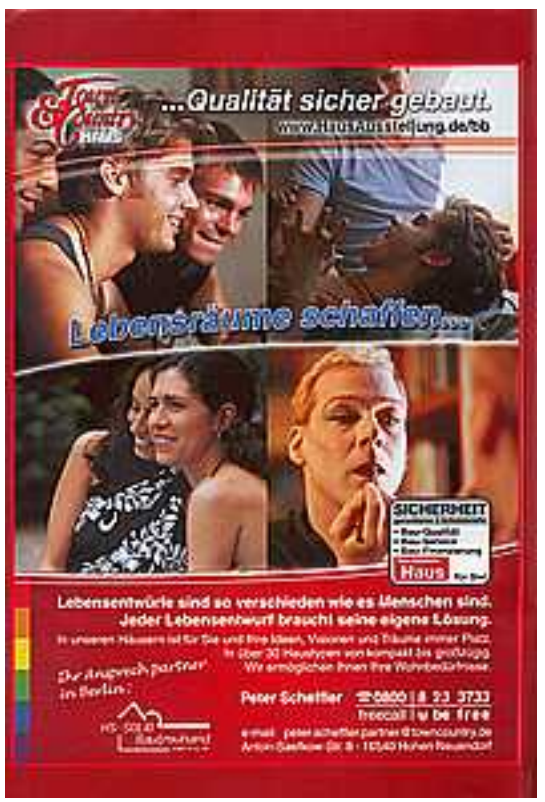

fig. 3Another ad may help to illustrate this particular aspect of queerness in neoliberalism. Once more this ad was placed on repeated occasions in an issue of Siegessaule. This time it has been taken out by the construction company Town \& Country Haus that proposes individual housing solutions to queer lifestyles (see fig. 3). It reads: "Creating Spaces for Living - Lifestyles are as numerous as there are human beings. Each lifestyle needs its own solution. Our houses give room to you and your ideas, visions, and dreams at any time. In over 30 different types of houses that range from compactly to generously spaced. We meet your housing demands." Unlike the
Deutsche Bank ad, this ad explicitly addresses queer people. The image border is adorned by a rainbow flag. The image centre shows two women and two men who, by their physic proximity, are likely to form a lesbian and a gay couple. Furthermore it displays a transgendered female person putting on makeup and finally three young and racially mixed men who might engage in a polyamorous gay relationship. What strikes me when I read the ad is yet another slogan: "Quality constructed safely." The word 'safety' reemerges once more at another place where an insurance cover for quality, service and funding is promoted. Although the ad does not guarantee safety from homophobic or transphobic assault, it evokes a need for safety that queer or coloured people might experience more than others.

While precariousness in neoliberalism increases for all, queer people or hybrid identities are more exposed to precariousness than others. We can discern winners and losers of neoliberal transformation even among queers but we cannot associate them to a clear-cut identity. Lisa Duggan (2003) has coined the notion of "homonormativity" as an analytical tool to describe co-optation of neoliberalism and gay lifestyle. Others have put forth the notion of "intersectionality".[7] It should be Queer Theory's task indeed to elaborate the various involvements into power hierarchies without presuming a homogeneous identity that allegedly affects all queer 
people. Queer analyses conceive of socio-economic hierarchies not as identities but as circumstances in which each individual is differently involved. Hence we should not assume a "precariat" whatsoever, but rather talk about the precarisation of life and work conditions.

This essay is the revised version of a paper given at the queer workshop "The Vagaries of Subjectivity", held in Warsaw on 14th of March 2008.

\section{Bibliography}

- Butler, Judith: Imitation and Gender Insubordination. In: Fuss, Diana (ed.): Inside/Out. Lesbian Theories, Gay Theories. New York/London 1991, pp. 13-31

- Butler, Judith: Undoing Gender. New York/London 2004

- Castel, Robert: From manual workers to wage laborers: transformation of the social question. New Brunswick, N.J. ; London 2003

- Clark, Danae: Commodity Lesbianism. In: Abelove, Henry et al. (eds.): The Lesbian and Gay Studies Reader. New York 1993, pp. 186-201 (original publication 1991)

- Duggan, Lisa: The Twilight of Equality. Neoliberalism, Cultural Politics and the Attack on Democracy. Boston 2003

- Foucault, Michel: The history of sexuality. New York 1978
- Hochschild, Arlie Russell: The managed heart: commercialization of human feeling. Berkeley, Calif. et al. 1983

- Kuster, Brigitta/Renate Lorenz: sexuell arbeiten. eine queere perspektive auf arbeit und prekares leben. Berlin 2007

- Munoz, Jose Esteban: Queerness's labor oder die Arbeit der Disidentifikation. In: Lorenz, Renate (ed.): Normal Love. Precarious Sex. Precarious Work. Berlin 2007, pp. 34-39

[1]

last visited on 9th of January 2009.

[2]

last visited on 9th of January 2009.

[3]

p.7, last visited on 9th of January 2009.

[4] http://www.db.com/careers/en/1539.html, last visited on 9th of January 2009.
[5]
Cf.
e.g. 
[6]

last visited on 9th of January 2009.

[7] Cf. http://en.wikipedia.org/wiki/Intersectionality, last visited on

9th of January 2009.

\section{Volker Woltersdorff}

